\title{
EVALUATION OF PEAR ROOTSTOCKS FOR THE CULTIVAR 'SUVENIRS' IN THE BALTIC REGION
}

\author{
Jānis Lepsis*, Līga Lepse*, Darius Kviklys**, and Neeme Univer*** \\ * Pūre Horticultural Research Centre, Abavas iela 2, Pūre, LV-3124, LATVIA; \\ janis.lepsis@puresdis.Iv \\ ** Institute of Horticulture, Lithuanian Research Centre for Agriculture and Forestry, Kauno st. 30, Babtai, Kaunas reg., LITHUANIA \\ ${ }^{\star * \star}$ Polli Horticultural Research Centre, Estonian University of Life Sciences Polli, 69108, Karksi-Nuia side, Viljandimaa, ESTONIA
}

Communicated by Edite Kaufmane

\begin{abstract}
In 2001, investigations were carried out on the Latvian origin cultivar 'Suvenirs' grafted on seven pear rootstocks (MA, MC, BA29, Pyrodwarf, Brokmal, Kirchensaller Mostbirne and Kazraušu bumbiere) in Polli (Estonia), Pūre (Latvia) and Babtai (Lithuania). The aim of the investigation was to evaluate pear rootstocks in different climatic conditions in the Baltic region. In Polli, all trees were planted in a dense planting, and therefore, trunk cross section area did not differ significantly between trees on different rootstocks. The most vigorous tree habit was observed in Lithuania for trees grafted on the rootstocks Kirchensaller Mostbirne and Brokmal, but in Latvia on Kirchensaller Mostbirne and Kazraušu bumbiere. The highest dwarfing effect was observed for rootstock $M C$ in both places. The highest cumulative yield from the orchard area was found for trees grafted on rootstocks of the quince group in all three locations of investigation. Nevertheless, the winter hardiness of the quince group rootstocks was not sufficient for Baltic climatic conditions. Good overwintering in Latvia and Lithuania was observed for trees on Pyrodwarf. Survival rate of trees grafted on Pyrodwarf in Estonia was unsatisfactory. The worse overwintering in Lithuania was observed for trees grafted on Brokmal. There was a dwarfing effect on trees and better yield on the vegetative propagated rootstocks included in the investigation, but none one of them can be recommended as perspective for commercial orchards in Baltic agro-climatic conditions.
\end{abstract}

Key words: Pyrus communis, tree survival, vegetative growth.

\section{INTRODUCTION}

The main problem in the pear orchard management is a lack of tree growth limiting (dwarfing) rootstocks. The commonly used pear rootstocks in the Baltic region are seedlings of local forms of Pyrus communis L. These rootstocks ensure good wintering ability of trees, but the drawback of these rootstocks is the vigorous growth of the trees. Therefore, it is necessary to look for new, dwarfing pear rootstocks suitable for Baltic climatic conditions. Quince $(\mathrm{Cy}$ donia oblonga) rootstocks, which are broadly used in Western Europe, probably have insufficient winter-hardiness in Baltic climatic conditions. In addition, most of the pear cultivars recommended for intensive orchards have insufficient physiological compatibility with quince. The area of pear orchards in the Baltic region is comparatively small - about 300 ha in total in the Baltic countries (Anonymous, 2012) and yields are associated with high risk. Nevertheless, there is an interest in growing of pears amongst growers in the Baltic countries.

In 1997, four horticultural research institutions of Estonia, Latvia, Lithuania and Byelorussia agreed on implementa- tion of a joint project for testing the same cultivar/ rootstock combinations of apples, pears and plums. The aim of the project was to evaluate apple, pear and plum rootstocks that had not been previously tested in the Baltic region, in the broadest area possible.

The climate of the Baltic States of East Europe is transitional between an Atlantic and continental climate. In the winter period, the temperature often drops below $-20{ }^{\circ} \mathrm{C}$ or even $-35^{\circ} \mathrm{C}$. After frost, a long period of thaw can follow. Such a winter temperature regime and cold summers are not suitable for growing of pear-rootstock combinations widely grown in Central and Western Europe. Therefore, cultivars suitable for local climatic conditions must be included in the proper evaluation of rootstocks in the orchard.

The aim of the paper is to summarize the results of the pear rootstocks evaluation in the Baltic countries.

\section{MATERIALS AND METHODS}

The trial was established in 2001 in the framework of the project "Baltic Fruit Rootstock Studies". In Lithuania, the 
trial was conducted at the Institute of Horticulture, situated at $55^{\circ} 06^{\circ} \mathrm{N} 23^{\circ} 48^{\circ} \mathrm{E}$. Trees were planted in EpicalcariEndohypogleyic cambisol soil with a high content of nutrients. The average yearly temperature is $+7.5{ }^{\circ} \mathrm{C}$ (the minimal winter temperature during the period of investigation (2001-2010) was $-30{ }^{\circ} \mathrm{C}$ ), the precipitation sum is $600-650$ $\mathrm{mm}$; precipitation during the vegetation period (May - October) is about $400 \mathrm{~mm}$.

The Latvian trial was conducted at the Pūre Horticultural Research Centre, situated at $57^{\circ} 02^{`} \mathrm{~N} 22^{\circ} 52^{`} \mathrm{E}, 50 \mathrm{~m}$ above the sea level. Trees were planted in brown soil with residual carbonates and mid-high contents of nuttrients. The average yearly temperature is $+7.3{ }^{\circ} \mathrm{C}$, the minimal temperature in winter can drop down to $-32{ }^{\circ} \mathrm{C}$, the precipitation sum is $600-700 \mathrm{~mm}$, and precipitation during the vegetation period (May - October) is about $300-350 \mathrm{~mm}$.

In Estonia the trial was conducted at the Polli Horticultural Research Centre, situated at $58^{\circ} 07^{`} N 25^{\circ} 32^{`}$ E. Trees were planted in sandy loam with mid-high contents of nutrients. Average yearly temperature is $+6.7^{\circ} \mathrm{C}$, the minimal temperature in winter can drop down to $-35^{\circ} \mathrm{C}$, and the precipitation sum is $600-700 \mathrm{~mm}$.

Periods with unfavourable meteorological conditions during the period from 2001 till 2012 caused damage to flower buds and also trees in several winters.

The cultivar 'Suvenīrs' of Latvian origin was used in all locations. It was grafted on five vegetatively propagated rootstocks: three quince (Cydonia oblonga) rootstocks - MA, MC and BA 29; two rootstocks originated from Pyrus communis - Borkmal $(\mathrm{OH} \times \mathrm{F} 333)$ and Pyrodwarf, and two seedling rootstocks from Pyrus communis - Kirchensaller Mostbirne and Kazraušu bumbiere. The vegetatively propagated rootstocks were virus-free, but the grafted cultivar was not tested for virus status. Cultivar 'Shtaras 31' of Lithuanian origin was used for double inoculation (nicolation) as inter-stock to prevent physiological incompatibility with quince rootstocks. The rootstocks of the quince (Cydonia oblonga) group (MA, MC and BA 29) are broadly used in Western Europe. Good propagation in stoolbed, good cropping efficiency and reduced tree growth are characteristic for these rootstocks (Wertheim, 1998). Selections of Pyrus communis (Brokmal and Pyrodwarf) have better winter hardiness in Europe and better compatibility in comparison to the quince group rootstocks (Jacob, 1996; Weber, 2001). The seedling rootstock Kirchensaller Mostbirne and seedlings of the local pear Kazraušu bumbiere were used as control.

Planting distances differed between the experimental locations. In Lithuania, planting distances for trees on quince group rootstocks, Pyrodwarf and Brokmal were $2 \times 4 \mathrm{~m}$ for Kirchensaller Mostbirne and $3 \times 4 \mathrm{~m}$ for Kazraušu bumbiere. In Latvia, planting distances for trees on quince group rootstocks were $2 \times 4 \mathrm{~m}$ for Pyrodwarf, $3 \times 4 \mathrm{~m}$ for Brokmal, and $5 \times 5 \mathrm{~m}$ for Kirchensaller Mostbirne and Kazrausu. In Estonia, planting distance for trees on all rootstocks was $4 \times 1.5 \mathrm{~m}$. The trials was designed as randomised blocks in three replications for each rootstock combination. In each plot three trees were planted. Weedfree strips (1-1.5 m wide) were maintained with herbicide applications along the tree rows. The grassed alleyways were mowed. Pest and disease management was carried out according to the rules of integrated plant protection. Irrigation was not used. The tial was stopped in Lithuania in 2010, but it continues in Latvia. Data analysis was performed for rootstocks groups by planting distances. Trunk cross section area (TCSA) was determined in all locations as parameter for evaluation of vegetative growth and tree productivity. TCSA was calculated from trunk diameter, measured 20-25 cm above the soil level. Mean fruit weight was measured in Lithuania and Estonia. Number of dead trees in each plot was recorded to evaluate rootstock suitability for growing in orchards in the local agro-climatic conditions.

Data were elaborated by the analysis of variance. Significance of differences between rootstocks means was evaluated using the Fisher LSD test at $P<0.05$. Rootstock effects were analysed for each location separately.

\section{RESULTS}

TCSA in 2010-2011 is summarised in Table 1. A significant effect of rootstock on TCSA was found in Latvia and Lithuania, but not in Estonia. A lower TCSA in Lithuania and Latvia was observed on rootstock MC. All three rootstocks of the quince group showed similar growth in Latvia, but in Lithuania differences between quince rootstocks were significant. In Lithuania, the Pyrus communis vegetatively propagated rootstocks Pyrodwarf and Brokmal were more vigorous than quince group rootstocks and Brokmal were more vigorous than Pyrodwarf. In Latvia, Pyrodwarf and Brokmal were evaluated separately and there were no significant differences observed between these rootstocks. In Lithuania, trees grafted on Kazraušu bumbiere were more vigorous than on Kirchensaller Mostbirne (both in the group of seedling rootstocks). In Latvia both seedling rootstocks had similar vegetative growth.

Table 1

TRUNK CROSS SECTION AREA OF TREES OF CULTIVAR 'SUVENĪRS' ON SEVEN ROOTSTOCKS AT THE END OF THE EXPERIMENT IN THREE LOCATIONS, $\mathrm{cm}^{2}$

\begin{tabular}{lcccc}
\hline \multicolumn{1}{c|}{ Rootstock } & Lithuania, 2010 & Latvia, 2011 & Estonia, 2011 \\
\hline BA29 & $85 \mathrm{c}$ & $64 \mathrm{a}$ & $78 \mathrm{a}$ \\
MC & $57 \mathrm{a}$ & $34 \mathrm{a}$ & - \\
MA & $72 \mathrm{~b}$ & $61 \mathrm{a}$ & $82 \mathrm{a}$ \\
Pyrodwarf & $97 \mathrm{~d}$ & $99 \mathrm{a}$ & $76 \mathrm{a}$ \\
Brokman & $111 \mathrm{e}$ & $101 \mathrm{a}$ & $83 \mathrm{a}$ \\
Kirchensaller Mostbirne & $113 \mathrm{~b}$ & $134 \mathrm{a}$ & $87 \mathrm{a}$ \\
Kazraušu bumbiere & $102 \mathrm{a}$ & $159 \mathrm{a}$ & $83 \mathrm{a}$
\end{tabular}

* values marked by different letters have significant difference (criteria of Fisher, $P=0.05$ ), rootstocks are grouped according to the planting distance 


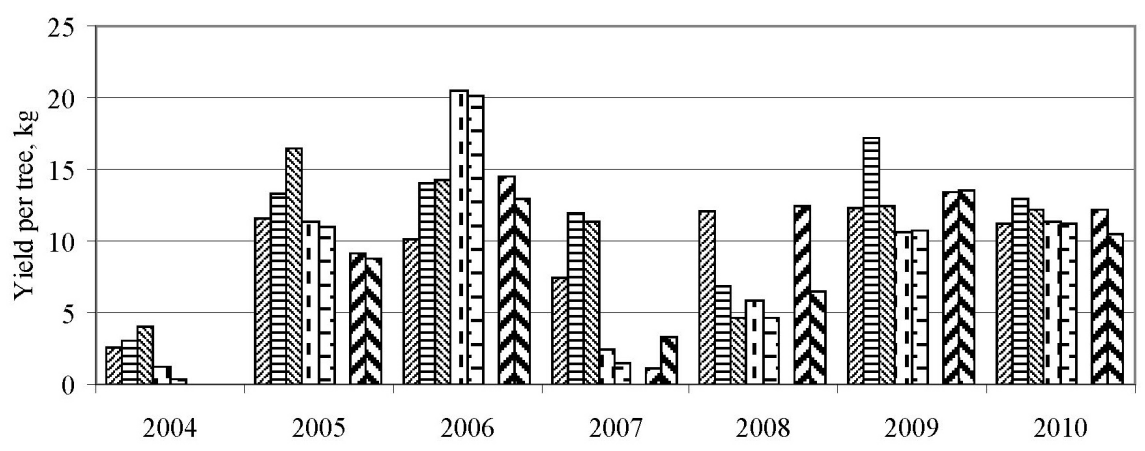

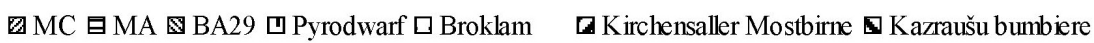

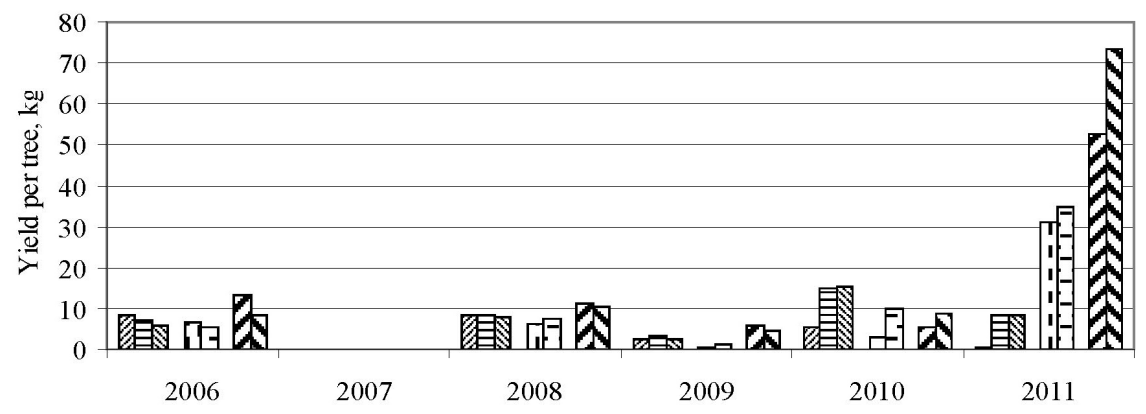

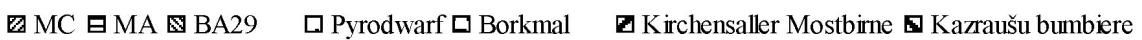

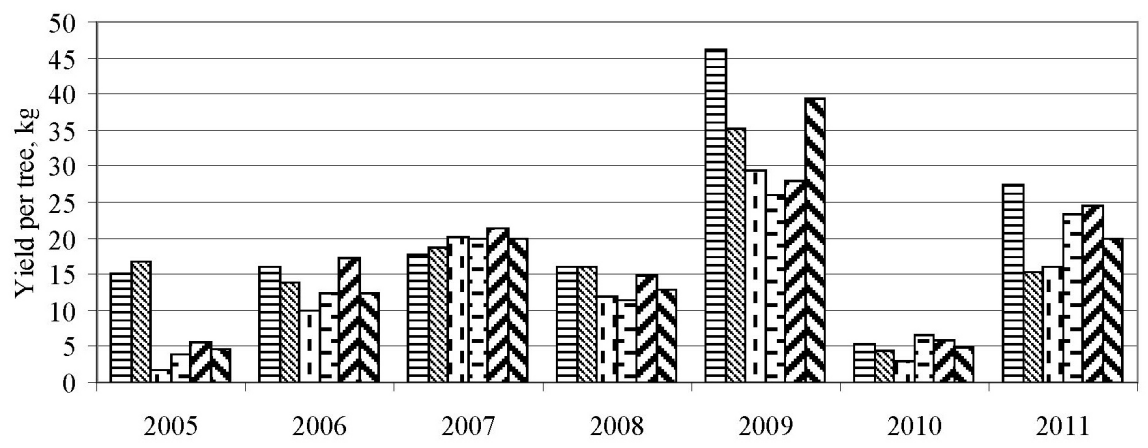

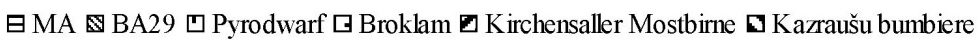

Fig. 1. Yield per tree of cultivar 'Suvenïrs' on seven rootstocks, Lithuania, 2001-2010

Fig. 2. Yield per tree of cultivar 'Suvenīrs' on seven rootstocks, Latvia, 2001-2011

Fig. 3. Yield per tree of cultivar 'Suvenīrs' on seven rootstocks, Estonia, 2001-2011

Table 2

The yield per tree in Lithuania was lower in 2007 and 2008 (Fig. 1). In Latvia, high yield per tree was observed in 2011, but yield was low in other years (Fig. 2). In Estonia, the average yield was $15-20 \mathrm{~kg}$ per tree; the highest yield was observed in 2009 and lowest in 2010 (Fig. 3). As yields were unstable from year to year, cumulative yield was used to evaluate tree productivity (Table 2). In Lithuania, the highest cumulative yield (79.8 kg per tree) was obtained from trees grafted on MA, but significant differences were not found for the other vegetative propagated rootstocks. In Latvia, significantly higher yield was obtained from trees on seedling rootstocks: $111 \mathrm{~kg}$ per tree on Kazraušu bumbiere and $83.3 \mathrm{~kg}$ per tree on Kirchensaller Mostbirne. In Estonia, the highest cumulative yield was harvested from trees on quince rootstocks: MA - 143.5 kg and BA29 - 120.2 kg per tree. A significantly lower yield was obtained from trees on Pyrodwarf.

The yield from the orchard area was directly influenced by planting distance (number trees per area). In Lithuania, the highest yield from a tree was obtained with denser planting
CUMULATIVE YIELD PER TREE OF CULTIVAR 'SUVENIRS' ON SEVEN ROOTSTOCKS AT THE END OF THE EXPERIMENT IN THREE LOCATIONS, $\mathrm{kg}$

\begin{tabular}{l|c|c|c}
\hline \multicolumn{1}{c|}{ Rootstocks } & $\begin{array}{c}\text { Lithuania, } \\
\text { 2001-2010 }\end{array}$ & $\begin{array}{c}\text { Latvia, } \\
2001-2011\end{array}$ & $\begin{array}{c}\text { Estonia, } \\
\text { 2001-2011 }\end{array}$ \\
\hline BA29 & $75.4 \mathrm{a}$ & $43.6 \mathrm{a}$ & $120.2 \mathrm{bc}$ \\
MC & $67.9 \mathrm{a}$ & $38.3 \mathrm{a}$ & \\
MA & $79.8 \mathrm{a}$ & $27.7 \mathrm{a}$ & $143.5 \mathrm{c}$ \\
Pyrodwarf & $63.4 \mathrm{a}$ & $48.9 \mathrm{a}$ & $93.5 \mathrm{a}$ \\
Brokmal & $59.5 \mathrm{a}$ & $59.0 \mathrm{a}$ & $103.1 \mathrm{ab}$ \\
Kirchensaller Mostbirne & $62.8 \mathrm{a}$ & $83.3 \mathrm{a}$ & $118.0 \mathrm{ab}$ \\
Kazraušu bumbiere & $55.5 \mathrm{a}$ & $111.1 \mathrm{~b}$ & $113.7 \mathrm{ab}$
\end{tabular}

* values marked by different letters have significant difference (criteria of Fisher, $P=0.05$ ), rootstocks are grouped according to the planting distance

(on rootstock MA) and also the highest yield per orchard area was obtained in this variant $-95.5 \mathrm{t} \mathrm{ha}^{-1}$. The lowest yield was harvested from trees on seedling rootstocks $52.3 \mathrm{t} \mathrm{ha}^{-1}$ on Kirchensaller Mostbirne and $46.2 \mathrm{t} \mathrm{ha}^{-1}$ on 
AVERAGE FRUIT WEIGHT FOR TREE OF CULTIVAR 'SUVENITRS' ON SEVEN ROOTSTOCKS IN SEPARATE YEARS AND IN WHOLE PERIOD OF THE EXPERIMENT IN LITHUANIA AND ESTONIA, $g$

\begin{tabular}{l|ccccc}
\hline \multicolumn{1}{c}{ Rootstocks } & $\begin{array}{c}\text { Lithuania, } \\
2009\end{array}$ & $\begin{array}{c}\text { Lithuania, } \\
\text { 2004-2010 }\end{array}$ & $\begin{array}{c}\text { Estonia, } \\
2009\end{array}$ & $\begin{array}{c}\text { Estonia, } \\
2007-2010\end{array}$ \\
\hline BA29 & $159 \mathrm{~b}$ & 154 & $114 \mathrm{ab}$ & 105 \\
MC & $158 \mathrm{~b}$ & 151 & - & - \\
MA & $135 \mathrm{a}$ & 152 & $118 \mathrm{~b}$ & 106 \\
Pyrodwarf & $155 \mathrm{~b}$ & 155 & $116 \mathrm{ab}$ & 107 \\
Brokmal & $162 \mathrm{~b}$ & 156 & $123 \mathrm{~b}$ & 112 \\
Kirchensaller Mostbirne & $159 \mathrm{a}$ & 157 & $114 \mathrm{ab}$ & 112 \\
Kazrausu bumbiere & $161 \mathrm{a}$ & 156 & $106 \mathrm{a}$ & 105
\end{tabular}

* values marked by different letters have significant difference (criteria of Fisher, $P=0.05$ ), rootstocks are grouped according to the planting distance

Kazraušu bumbiere. The highest yield from a tree in Latvia was obtained from trees on seedling rootstocks, but due to planting distances, the highest yield from an orchard area was harvested from trees on Pyrodwarf $-57 \mathrm{t} \mathrm{ha}^{-1}$, and lowest on Kazraušu bumbiere - $33.3 \mathrm{t} \mathrm{ha}^{-1}$. In Estonia all trees were planted in the same density, therefore the evaluation results of obtained yield per area correspond to the yield from a tree.

Average fruit weight was measured in Lithuania and Estonia (Table 3). In Lithuania fruit weight was not influenced by rootstock; average fruit mass was between $151 \mathrm{~g}$ (on rootstock MC) and $157 \mathrm{~g}$ (on Kirchensaller Mostbirne). However, significant differences between trees on different rootstocks were found in three of six years. The lowest average fruit mass was observed for trees on MC, in two years for trees on BA29, MA and Pyrodwarf. In Estonia, average fruit mass was measured in four years. Fruit mass was not significantly affected by rootstock, and varied between $105 \mathrm{~g}$ (on rootstocks BA29 and Kazraušu bumbiere) and $112 \mathrm{~g}$ (on Kirchensaller Mostbirne and Brokmal). Some differences were observed in specific years. In 2009 (year with highest yield), larger fruits were harvested from trees on rootstocks Broklam and MA, but lower on Kazraušu bumbiere.

Tree survival rate in Lithuania was better on Pyrodwarf, Kazraušu bumbiere and Kirchensaller Mostbirne, and lower on Brokmal and MC (Fig. 4). 100\% tree survival in Latvia was recorded on Brokmal and Kirchensaller Mostbirne, high survival rate on Kazraušu bumbiere and Pyrodwarf, and the lowest on MC. In Estonia, better tree survival rate was observed on Kirchensaller Mostbirne and Kazraušu bumbiere, and the lowest on Pyrodwarf.

\section{DISCUSSION}

Trunk cross section area (TCSA) is one of the widely used parameters for characterisation of tree vegetative growth. In Lithuania and Latvia, the lowest TCSA was observed for trees grafted on MC (in Estonia this rootstock was not planted). This is in accordance with the reports of other investigations of pear rootstocks (Wertheim, 1989; Iglesia et al., 2004). Results in Latvia and Estonia indicate a similar influence of rootstocks Brokmal and quince BA29 on the tree growth, as reported previously (Webster, 2003; Alonso et al., 2011). In Lithuania trees grafted on rootstock Brokmal were more vigorous than those grafted on BA29, as found in other investigations (Stern and Doron, 2009). It has been reported that tree growth on rootstock Pyrodwarf is intermediate to that on quince and Brokmal (Jacob, 1996; Robinson, 2011). This was observed also in Latvia and Lithuania, although the difference was not statistically significant. In Estonia TCSA for trees grafted on Pyrodwarf was even slightly less than on MA and BA29. Vigorous growth of offshoots has to be mentioned as a drawback for Pyrodwarf (Lepsis and Drudze, 2011; Robinson, 2011).

In Estonia, trees were planted in very dense planting, which prevents the development of normal growth of trees with stronger vigour. Therefore, significant differences between rootstocks were not found. Iglesia et al. (2004) observed differences between seedling rootstock, Brokmal and quince rootstocks in Spain in orchards with planting distance $1.5 \times$ $4 \mathrm{~m}$.

A site effect on TCSA was observed. More vigorous tree growth occurred in Lithuania, compared to the two other locations. Trees on quince group rootstocks were planted in similar densities in all locations, and this provided better insight on the influence of location on tree growth. The biggest TCSA was observed for trees grafted on all quince rootstocks in Lithuania (comparing data of 2010). More

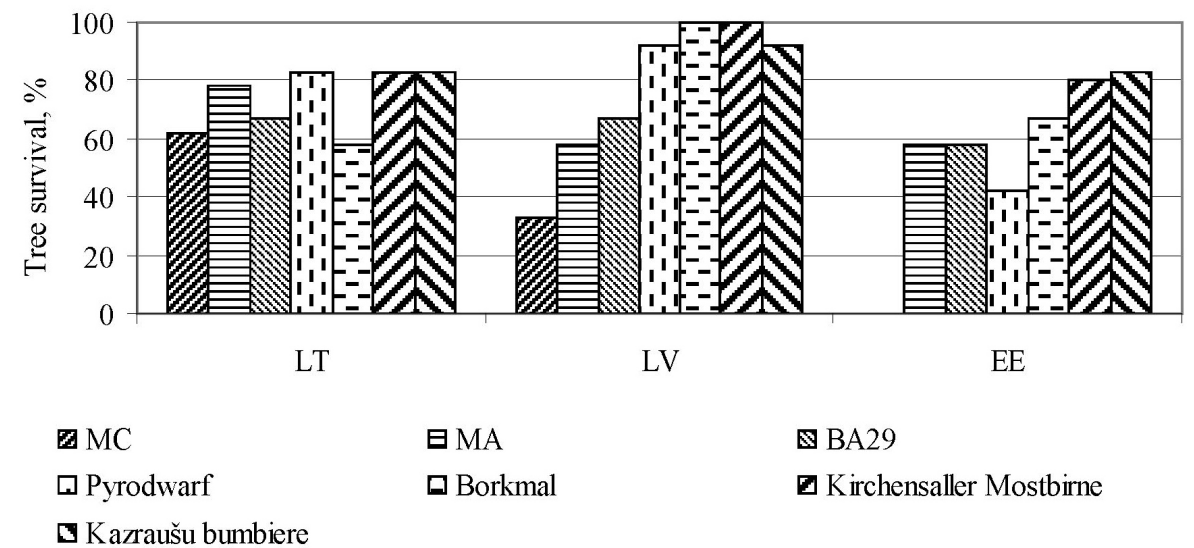

Fig. 4. Tree survival rate for trees of cultivar 'Suvenīrs' on seven rootstocks in three locations, 2001-2011 
vigorous growth of trees in Lithuania than in Latvia and Estonia was observed previously in other trials (Univer et al., 2010). The main reasons for the higher vigour could be more fertile soil and more favourable meteorological conditions. However, the yield was lower in Lithuania than in Estonia. Thus, only vegetative growth differed in Lithuania. Soil and climate cannot be the main reason for vigorous tree development, as shown in the results of other trials (Kviklys et al. 2012; Univer et al., 2010).

The cumulative yield differed between locations. The highest yield in Lithuania and Estonia were obtained from trees grafted on the rootstocks of the quince group, as found also in Spain (Iglesia et al., 2004). The yield of trees on rootstock Brokmal in Lithuania was similar to other rootstocks of the quince group. In Estonia, yield was similar for trees on BA29, and these were lower than on MA. Contrasting results have been obtained for yield on Brokmal; lower yields have been obtained on Brokmal than on quince (Iglesia et al., 2004) and also higher yields (Stern and Doron, 2009). Some authors indicate the influence of the cultivar on this parameter (Alonoso et al., 2011). The highest yields in Latvia were obtained on seedling rootstocks, which can be explained by the more vigorous growth of trees and sparser planting distance. In Lithuania, the yield from trees on quince group rootstocks exceeded the yield from trees on seedling rootstocks, but trees on the seedling rootstocks were planted sparser. However, the difference in planting densities $(2 \times 4 \mathrm{~m}$ for quince rootstocks and, $3 \times 4$ $\mathrm{m}$ for seedlings) was very slight, and thus the most significant effect was likely due to the rootstock properties. The first yields were higher on quince rootstocks (Fig. 1) and also in 2007 when yield on seedling rootstocks was weak, trees on quince rootstocks had average yield.

Average fruit weight was not influenced by rootstock in Lithuania and Estonia for the whole period. Alonso and Iglesias (Alonoso et al., 2011, Iglesia et al., 2004) found that average fruit weight for trees grafted on Brokmal can be less than that on trees grafted on BA29. This was not observed in Lithuania and Estonia. Fruit weight in Estonia was less than in Lithuania, perhaps due to both yield and denser planting. The influence of planting density on the average fruit weight was also noted in other investigations (Policarpo et al., 2006).

One of the main parameters indicating suitability of a rootstocks to a particular conditions is tree survival rate. As expected, good tree survival rate was found on the seedling rootstocks in all locations. However, trees grafted on Pyrodwarf show good to satisfactory survival in Latvia and Lithuania. This rootstock is known to be more winter-hardy than rootstocks of the quince group (Jacob, 1996; Lewko et al., 2007; Robinson, 2011). In Estonia trees on Pyrodwarf rootstock had the worst overwintering survival. Rootstock Brokmal showed good results in Latvia, but insufficient overwintering in Lithuania and Estonia. Pyrodwarf had better survival than Brokmal in Lithuania, which is in ac- cordance with the results of investigations carried out in Poland (Lewko et al., 2007), but in contrast to that observed in Estonia. Detailed analysis of meteorological conditions is needed to determine the reasons for tree death.

In summary we can conclude that:

- rootstocks of the quince group have a dwarfing effect on the trees, ensure good yield, but they have insufficient survival in Baltic conditions;

- the Pyrus communis vegetative propagated rootstocks Pyrodwarf and Brokmal have some dwarfing effect on trees, but we have no unambiguous conclusions about their influence on tree survival;

- no suitable alternative for Pyrus communis seedlings rootstocks was found. These rootstocks have a lower growing risks, but vigorous tree habit should be mentioned as a drawback.

\section{REFERENCES}

Alonso, J. M., Gomerz-Aparisi, J., Anson, J. M., Espiau, M. T., Carrera, M. (2011). Evaluation of the OHxF selections as an alternative to quince rootstocks for pears: Agronomical performance of 'Conference' and 'Doyenne du Comice'. Acta Hort., 903, 451-455.

Anonymous (2012). Eurostat. http://epp.eurostat.ec.europa.eu/

Iglesias, I., Asisn, L., Montserrat, R., Vilaredell, P., Carbo, J., Bonany, J. (2004). Performance of some pear rootstocks in Lleida and Girona (Catalonia, NE-Spain). Acta Hort., 658, 159-165.

Jacob, H. (1996). Pyrodwarf: Eine neue Klonunterlage fur den intensiven Birnenbau. Erwerbsobstbau, 38, 166-169.

Kviklys, D., Kviklienė, N., Bite, A., Lepsis, J., Univer, T., Univer, N., Uselis, N., Lanauskas, J., Buskiene, L., (2012). Baltic fruit rootstock studies: Evaluation of 12 apple rootstocks in North-East Europe. Hort. Sci. (Prague), 39 (1), pp. 1-7.

Lepsis, J., Drudze, I. (2011). Evaluation of seven pear rootstocks in Latvia. Acta Hort., 909, 457-459.

Lewko, J., Scibisz, K., Sadowski, A. (2007). Performance of two pears cultivars on six different rootstocks in the nursery. Acta Hort., 732, 227-231.

Policarpo, M., Talluto, G., Lo Bianco, R. (2006). Vegetative and productive responses of 'Conference' and 'Williams' pear trees planted at different in-row spacings, Sci. Hort., 109. 322-331.

Robinson, T. L. (2011). High density pear production with Pyrus communis rootstocks. Acta Hort., 909, 259-269.

Stern, R. A., Doron, I. (2009). Performance of 'Coscia' pear (Pyrus communis) on nine rootstocks in the north of Israel. Sci. Hort., 119, 252-256.

Univer, T., Kviklys, D., Lepsis, J., Univer, N. (2010). Early performance of 'Auksis' apple trees on dwarfing rootstocks in the Baltic region. Agron. Res., 8 (special issue 3), 743-748.

Weber, I. H. (2001). Birnenunterlagen fur den Intensivanbau. Erwerbsobstbau, 43, 99-105.

Webster, A. D. (2003). Breeding and selection of apple and pear rootstocks. Acta Hort., 622, 499-512

Wertheim, S. J. (1989). Prelimenary results of trials with dwarfing apple and pear rootstocks. Acta Hort., 243, 59-70.

Wertheim, S. J. (1998). Rootstock Guide. Apple, Pear, Cherry, European Plum. The Netherlands, Fruit Research Station Wilhelminadorp. 144 p. 


\section{BUMBIERU POTCELMU VĒRTĒJUMS ŠĶIRNEI 'SUVENİRS' BALTIJAS REĢIONĀ}

Bumbieru potcelmu izmēǵinājums sākts 2001. gadā, kad Latvijas selekcijas šḳirne 'Suvenīrs' uz septiniem potcelmiem iestādīts Polli (Igaunija), Pūrē (Latvija) un Babtai (Lietuva). Pētījuma mērḳis bija novērtēt potcelmus (QA, QC, BA29, Pyrodwarf, Brokmal (OH×F333), Kirschentaler Mostbirne un Kazraušu bumbiere) iespējami plašākā teritorijā. Igaunijā visi potcelmi stādīti blīvā stādījumā, tāpēc koku stumbra škēersgriezuma laukums starp potcelmiem būtiski neatškīiās. Lietuvā spēcīgāks veǵetatīvais augums konstatēts kokiem uz potcelma Kirschentaler Mostbirne un Brokmal, bet Latvijā - uz Kirschentaler Mostbirne and Kazraušu bumbieres. Abās vietās koku veǵetatīvo augumu visvairāk ierobežoja potcelms QC. Visās izmēǵinājuma vietās augstākā kumulatīvā raža no dārza platības bija kokiem uz cidoniju grupas potcelmiem. Tomēr šo potcelmu ziemcietība Baltijas apstākḷıs nav pietiekoša. Labāks koku izdzīvošanas vērtējums Latvijā bija potcelmiem Pyrodwarf un Brokmal. Savukārt Igaunijā potcelma Pyrodwarf izdzīvošanas vērtējums bija neapmierinošs, bet Lietuvā neapmierinoša izdzīvošana bija kokiem uz Brokmal. Izmantotie sēklaudžu potcelmi nodrošina labu koku izdzīvošanu, taču koku augums ir lielāks, bet ražas no dārza platības zemākas. Pētījumā iekḷautie veǵetatīvi pavairojamie potcelmi samazina koku augumu, taču nevienu no tiem nevar rekomendēt, kā piemērotu komerciāliem stādījumiem Baltijas valstīs. 